\title{
Почему Арендт?
}

\author{
Алексей Саликов \\ Кандидат философских наук, ведущий научный сотрудник Центра фундаментальной социологии \\ Национального исследовательского университета «Высшая школа экономики» \\ Адрес: ул. Мясницкая, д. 20, г. Москва, Российская Федерация 101000 \\ E-mail: dr.alexey.salikov@gmail.com
}

Есть философы, имена которых известны всем: Платон, Аристотель, Кант. О них пишут в школьных учебниках по обществознанию, их изучают в университетских курсах по философии, о них стыдно не знать образованному человеку. Есть философы, имена которых никому, кроме специалистов, не известны. Таких большинство. И есть философы, имена которых известны многим, но слава которых очень неоднозначна. Это случай Арендт, мыслителя глубокого, неординарного и противоречивого. Чем же так знаменита Ханна Арендт и чем она может быть интересна отечественному читателю?

На Западе Арендт по праву считается одним из классиков современной политической мысли. Ее работам посвящаются многочисленные научные симпозиумы, год от года растет количество публикаций о ней. Ее именем названы улицы и скорые поезда. Учреждена премия имени Ханны Арендт - за вклад в политическую мысль. Существуют несколько центров по изучению ее теоретического наследия, ее имя носят научно-исследовательские институты. Все это подтверждает слова Курта Зонтхаймера о том, что Хана Арендт стала в современном западном мире своего рода иконой, символом нашего времени ${ }^{1}$. Славу Арендт принесли прежде всего ее исследование феномена тоталитаризма (книга «The Origins of Totalitarianism» ${ }^{2}$ ), репортажи с процесса над нацистским преступником Адольфом Эйхманом («Eichmann in Jerusalem» ${ }^{3}$ ), а также анализ проблем политического в условиях современного массового общества («The Human Condition» ${ }^{4}$ ).

В России Арендт сегодня один из самых недооцененных современных философов. Да, за последние 20 лет, начиная с середины 1990-х годов, когда стали появляться переводы трудов Арендт на русский язык, имя ее стало о чем-то говорить образованному отечественному читателю, но другое дело - «о чем» оно говорит. К сожалению, по большей части это штампы и ярлыки, закрепившиеся за ней в России в процессе «широкой» рецепции и обусловленные нехваткой фундамен-

\footnotetext{
(c) Саликов А. Н., 2017

(c) Центр фундаментальной социологии, 2017

DOI: $10.17323 / 1728-192 \mathrm{X}-2017-2-218-220$

1. Sontheimer K. (2005). Hannah Arendt: Der Weg einer grossen Denkerin. München: Piper. S. 9-10.

2. Arendt H. (1951). The Origins of Totalitarianism. New York: Harcourt, Brace \& World.

3. Arendt H. (1963). Eichmann in Jerusalem: A Report on the Banality of Evil. New York: Viking Press.

4. Arendt H. (1958). The Human Condition. Chicago: University of Chicago Press.
} 
тальных исследований и дискуссий о ее философии. Репутация Арендт как «поверхностного» («Гегель в комиксах» ${ }^{5}$ ), «устаревшего» ${ }^{6}$ или «либерального» философа вызвана самыми разными причинами. Это и недостаток исследований, и специфические проблемы с русскими переводами, а также с переводами работ других философов, психологов, социологов и политологов, составляющих необходимый для ее рецепции контекст ${ }^{7}$. На первый взгляд ситуация с переводами текстов довольно неплохая, основные работы Арендт в настоящий момент доступны на русском: «Истоки и смысл тоталитаризма» ${ }^{8}$ (1996), «Vita activa, или О деятельной жизни» ${ }^{9}$ (20о0), «Банальность зла. Эйхман в Иерусалиме» ${ }^{10}(2008)$, «Жизнь ума» ${ }^{11}$ (2013) и др. Однако многие из существующих переводов не лишены определенных недостатков, которые обусловлены как объективными (двуязычие Арендт, разнообразие изданий ее работ, отсутствие устоявшегося канона, т. е. академического собрания ее трудов в англоязычной и немецкоязычной традиции), так и субъективными обстоятельствами (неглубокое знание работ Арендт, поспешность перевода без научного редактирования, отсутствие необходимого научного аппарата, вводных статей, предисловий и послесловий). (К слову, мы планируем опубликовать в одном из номеров «Социологического обозрения» специальное исследование, посвященное анализу имеющихся русских переводов трудов Арендт.) Другой проблемой является то, что, по сути, в России до сих пор нет систематического исследования философии Арендт: не так много, как хотелось бы, публикуется статей и выходит монографий, мало защищается диссертаций. В стране не сложился пока и сколь-нибудь значимый центр арендтоведения, остро ощущается нехватка научных мероприятий: за все время с начала 1990-х годов прошло всего несколько небольших конференций и круглых столов, посвященных идеям Арендт (в Калининграде и Санкт-Петербурге, а также в Москве).

Такая ситуация с исследованием философии Арендт выглядит особенно печально, учитывая то обстоятельство, как много внимания в ее работах уделяется Советской России и СССР. Более того, Арендт затрагивает многие злободневные, в том числе и для современной России, темы: триумф бюрократии и дегуманизация общества, отмирание политики как сферы реализации человеческой свободы и общий нигилизм, мышление в контексте исторического опыта травмы (в отличие от более знаменитого, но и более узкого обсуждения мышления после Холокоста), злоупотребление эмоциональными (и, более широко, моральными)

5. http://www.guelman.ru/slava/nrk/nrk5/19.html

6. http://n-europe.eu/tables/2014/o1/28/nasledie_khanny_arendt_segodnya

7. См. доклад А. Г. Жаворонкова на круглом столе «Творчество Ханны Арендт и современность», состоявшемся в ИФ РАН 20 октября 2016 г.

8. Арендт Х. (1996). Истоки тоталитаризма / Пер. с англ. И. В. Борисовой, Ю. А. Кимелева, А. Д. Ковалева, Ю. Б. Мишкенене, Л. А. Седова под ред. М. С. Ковалевой и Д. М. Носова. М.: ЦентрКом.

9. Арендm X. (2000). Vita activa, или О деятельной жизни / Пер. с нем. и англ. В. В. Бибихина. СПб.: Алетейя.

10. Арендт Х. (20о8). Банальность зла. Эйхман в Иерусалиме / Пер. с англ. С. Кастальского и Н. Рудницкой. М.: Европа.

11. Арендт X. (2013). Жизнь ума / Пер. с англ. А. В. Говорунова. СПб.: Наука. 
аргументами в политической сфере, а также вопросы о личной ответственности за коллективные действия и о разграничении публичного и частного ${ }^{12}$. Все вышесказанное отчетливо свидетельствует о том, что в России назрела насущная потребность в серьезном и систематическом изучении идейного наследия Арендт.

Ранее наш журнал уже публиковал материалы, связанные с Ханной Арендт: статьи А. Глухова ${ }^{13}$ и М. Сидоровой ${ }^{14}$, переводы интервью Ханны Арендт с Гюнтером Гаусом ${ }^{15}$ и Карло Шмидом ${ }^{16}$, предисловие переводчика к интервью Арендт и Карло Шмида ${ }^{17}$, отчет о международной конференции в Калининграде ${ }^{18}$, рецензию ${ }^{19}$ М. Юрловой на сборник «Между прошлым и будущим» в переводе Д. Аронсона. Однако нам кажется, что этого сегодня уже недостаточно. Нужен свежий взгляд, который бы позволил взглянуть на ее философию без предрассудков и стереотипов. Нужно то, что Арендт называла «новым началом» - поступок, инициатива, через которую, собственно, и раскрывается деятельная сущность человека.

И наш журнал принял решение проявить эту инициативу. С этого номера «Социологическое обозрение» открывает постоянную рубрику «Ханна Арендт: новое начало», в которой мы планируем публиковать материалы, так или иначе связанные с ее теоретическим наследием: статьи, переводы, рецензии, обзоры и отчеты о конференциях. Мы будем делать это регулярно и надеемся, что новая рубрика станет дискуссионной площадкой для отечественных и зарубежных исследователей, центром притяжения всех интересующихся философией Арендт.

12. См. доклад А. Г. Жаворонкова на круглом столе «Творчество Ханны Арендт и современность», состоявшемся в ИФ РАН 20 октября 2016 г.

13. Gloukhov A. (2015). Arendt on Positive Freedom // Социологическое обозрение. Т. 14. № 2. С. 9-22.

14. Сидорова M. (2016). Прощение как опыт возможного: подходы Х. Арендт и П. Рикера // Социологическое обозрение. Т. 15. № 2. С. 192-207.

15. Арендт X., Гаус Г. (2013). Разговор с Гюнтером Гаусом: телевизионное интервью (октябрь 1964 г.) / Пер. с нем. Г. Дашевского // Социологическое обозрение. Т. 12. № 1. С. 3-23.

16. Арендт Х., Шмид К. (2016). Право на революцию: разговор между профессором Карло Шмидом и философом Ханной Арендт / Пер. с нем. А. Саликова // Социологическое обозрение. Т. 15 . № 1. C. $56-74$.

17. Саликов А. (2016). Предисловие к публикации «Право на революцию» // Социологическое обозрение. Т. 15. № 1. С. 54-55.

18. Саликов А. (2014). Философский зоопарк в Калининграде: международная конференция «Современное значение идей Ханны Арендт» // Социологическое обозрение. Т. 13. № 3. С. 219-222.

19. Юрлова М. (2014). «Между прошлым и будущим»: упражнения в политической мысли в отсутствие твердой опоры // Социологическое обозрение. Т. 13. № 3. С. 223-237. 